九州大学学術情報リポジトリ

Kyushu University Institutional Repository

Factors Influencing Pesticide and Fertilizer Use and Policy Options toward More Sustainable Farming Systems : An Empirical Analysis of Kyushu Agriculture

$\mathrm{Bai}, \mathrm{Hu}$

Agricultural Economics Laboratory, Division of Bioresource and Bioenvironmental Sciences, Kyushu University

https://doi.org/10.5109/24349

出版情報 : 九州大学大学院農学研究院紀要. 44 (3/4)，pp.483-494，2000-02. Kyushu University バージョン：

権利関係 : 
J. Fac. Agr., Kyushu Univ., $44(3 \cdot 4), 483-494(2000)$

\title{
Factors Influencing Pesticide and Fertilizer Use and Policy Options toward More Sustainable Farming Systems: An Empirical Analysis of Kyushu Agriculture
}

\author{
Hu Bai \\ Agricultural Economies Laboralory, Division of Bioresource and Bioenvirommental \\ Sciences, Kyushu University, Fukuoka 812-8581. Japan \\ (Received October 28, 1999 and accepted November 5, 1999)
}

\begin{abstract}
This study cxamines the factors influencing pesicide and fertilizer use and analyzes the possible impact of reducing the application rates of the lwo inpuls on product supply, farm income, and input structure. A land-productivity-specitic model is estimated using the data of farm households from Kyushu. The substitutability and complementarity between factors are found to be the main deteminants influcncing the use of pesticides and fertilizer, while the effects of product prices are not detcrminate. The conditions for redursing the application rates of the two inputs have been favorable, and consequently the widespread adoption of low-input sustainable farming (LISF) systems is likely to be realized at. lower opportunity cost. Pricc or tax measures aimed at restricting agrichemical use seem not to be effective as might be expected. The policy measures making LiSF practices more protitable may effectively motivate farmers to adopt these practices. A functional transition of regional farming service system! from agrichemical-using to more environmentally sensitive practices is also required.
\end{abstract}

\section{INTRODUCTION}

Over the last 10 years, farming systems aimed at making agriculture environmentally safer by reducing agrichemical use and/or adopting soil-conservation cultivation, have been widely discussed in Japan. The growing concern for environmental issues associated with pesticide and fertilizer application has brought about innovative changes both in farming practice and in the formulation of agricultural policy more generally. According to a survey by the Statistics and Information Department, the Ministry of Agriculi.ure, Foresiry and Fisheries (SIDMAFF, 1997), 5\% of farmers have adopted low-input sustainable farming (LISF) practices in rice production, the stable food crop of Japanese. Some policy proposals cmanating from the discussions have been enacted into law. Evidence of this is that three agroenviromment acts (namely, the Act Concerning Promoting Adoption of More Sustainable Farming Systems, the Revised Fertilizer Regulation Act, and the Act Concerning Proper Management and Ltilization Promotion of Livestock Excreta), cleared the Diet in July, 1999.

Such changes have attracted extensive attention, as they indicatc a transition from convertional farming to environmentally more sustainable production systems. Japanese agriculture is generally typified by small farm size and high land productivity. Fertilizer responsive varieties and intensifying input use have been the key factors of high yield in a long-run term after the war. The transition to LISF systems is likely to result in wide-ranging effects on product supply and input demand, which then possibly return to influence the extension of LISF practices. Effective policy actions in line with the three 
acts are, therefore, required to take into account the possible impact of reducing pesticide and fertilizer use on yields, farm incomes, and input structure.

Some policy measures for promoting the adoption of LISF practices have been proposed. They mainly include subsidies for LISF farmers, administrative restriction on the use of pesticides and nitrogen fertilizer, and user fees or "polluter-pays", etc. Lnfortunately, few empirical researches have been done to provide full evidence for these proposals, though a number of studies have been reported in North America and other regions (see the review by Fox et al., 1991; Daberkov et al., 1988; Widawsky et al, 1998). To examine the feasibility or effectiveness of such policy proposals, this study analyzes the factors influencing pesticide and fertilizer use as well as the possible impact of reducing the application rates of the two inputs on product supply, farm incomes, and inpul demand, by developing a land-productivity-specific model. Considering the diversity of agriculture across regions, the data from Kyushu, an agricultural region in southwest Japan, are used.

\section{Structural changes and the use of pesticides and fertilizer in Kyushu}

Kyushu is a representative agricultural region which has undergone rapid and diversified agricultural devclopment since the 1960s. As shown in Table 1, this region accounted for $20 \%$ of domestic farm outpul, with only $12 \%$ of farm land in 1997 . During the 1960-97 period, the major crops, vegetable-fruit-flowers, industrial crops, and livestock, all exhibited high share growth rates ranging from $7 \%$ to $10 \%$. These make Kyushu the most important producing base in fresh product supply.

The expansion of high-value crops generally means an increase in pesticide and fertilizer use because of the higher input intensily of such factors in the production of these crops. This process is further accelerated by the rapid decrease in farm workers, as a result of the extension of off-farm employment and the withdrawal of aged farmers. From 1960 to 1997 , farm workers decreased by $69 \%, 3 \%$ higher than the national mean level. The increasing labor shortage led to a continuous rise in relative price ratios of wage rate versus pesticides and fertilizer, and consequently facilitating substitution of the two inputs for farm labor. As a result, pesticide and fertilizer use per hectare measured in constant 1990 prices has largely grown (Table 1). Application rates of pesticides in 1997 were higher than the national mean levels by $25 \%$ at planted area base and $39 \%$ at cultivated area base, while the levels of fertilizer use were higher by $6 \%$ and $18 \%$ respectively.

A key institutional measure in pest controlling, which was designed to meet the requirement of raising land productivity while saving labor, is the "Joint Pest. Management System" introduced in the 1960 s. Its distinctive feature is "joint and simultaneous chemical spraying" in rural community or town units, supported technically by agricultural extension agencies and agricultural cooperatives. However, by substituting joint action for closer plot-monitoring of pest levels and farm-specific control measures, this system is considered to have significantly caused the overuse of agrichemicals (Une, 1987), through it has undoubtedly played important roles in reducing production loss from pest infestations. Concern about the performance of this system has derived a request to re-avaluate the roles of conventional regional farming service system in the development of agriculture, which mainly consists of agricultural extension system and 
Table 1. Structural Changes, Use of Pesticides and Fertilizer, and Productivities in Agriculture of Kyushu: Some Representalive Years

\begin{tabular}{|c|c|c|c|c|c|c|c|c|c|}
\hline & 1960 & 65 & 70 & 75 & 80 & 85 & 90 & 95 & 97 \\
\hline \multicolumn{10}{|l|}{ I. Kyushu's shares in tational } \\
\hline 1. Cultivated area & 13.9 & 14.1 & 14.0 & 13.5 & 13.2 & 13.0 & 12.7 & 12.5 & 12.4 \\
\hline 2. Gross farm output & 15.0 & 15.5 & 15.2 & 16.7 & 18.1 & 18.5 & 20.0 & 20.0 & 20.4 \\
\hline Rice & 12.8 & 14.0 & 12.1 & 13.0 & 12.3 & 11.1 & 11.2 & 11.2 & 10.9 \\
\hline Vegetable, fruits \& flower & 11.2 & 12.0 & 13.3 & 13.7 & 14.2 & 15.7 & 17.2 & 17.2 & 18.0 \\
\hline Industrial crops & 21.3 & 21.9 & 23.6 & 25.8 & 25.8 & 25.2 & 27.8 & 27.8 & 31.6 \\
\hline Livestock & 15.0 & 13.5 & 14.4 & 18.0 & 20.2 & 21.5 & 23.4 & 23.1 & 23.3 \\
\hline \multicolumn{10}{|l|}{ II Pesticide \& fertilizer use } \\
\hline \multicolumn{10}{|l|}{ 1. Pesticides } \\
\hline Real value $(¥ 1000 / \mathrm{ha})$ & 8 & 14 & 35 & 70 & 88 & 102 & 111 & 124 & 127 \\
\hline$\%$ to national mean & 91.7 & 93.5 & 109.0 & 131.7 & 129.2 & 122.4 & 120.4 & 124.5 & 125.2 \\
\hline & $(108)$ & $(110)$ & $(121)$ & $(142)$ & $(142)$ & (143) & $(138)$ & (142) & $(139)$ \\
\hline \multicolumn{10}{|l|}{ 2. Fertilizer } \\
\hline Real value( $¥ 1000 / h a)$ & 55 & 73 & 105 & 108 & 105 & 112 & 121 & 127 & 128 \\
\hline \multirow[t]{2}{*}{ o to natiorlal mean } & 88.9 & 99.3 & 102.6 & 103.8 & 98.9 & 96.8 & 103.5 & 107.2 & 105.8 \\
\hline & (104) & $(110)$ & (114) & $(110)$ & $(309)$ & $(113)$ & (118) & (123) & (118) \\
\hline \multicolumn{10}{|l|}{ III. Productivity } \\
\hline \multirow{2}{*}{\multicolumn{10}{|c|}{$\begin{array}{l}\text { 1. Real output value of field } \\
\text { crops ( } ¥ 1000 \text { por farm worker) }\end{array}$}} \\
\hline & & 587 & 658 & 967 & 1029 & 1215 & 1412 & 1779 & - \\
\hline Rates to national mean & 0.81 & 0.87 & 0.82 & 0.86 & 0.89 & 0.90 & 0.99 & 1.07 & - \\
\hline \multicolumn{10}{|l|}{ 2. Real output value of field } \\
\hline crops ( $¥ 1000$ per hectare) & 756 & 899 & 1076 & 1450 & 1385 & 1500 & 1650 & 1989 & 2060 \\
\hline Rates to national mean & 0.79 & 0.85 & 0.81 & 0.93 & 0.97 & 0.67 & 1.09 & 1.20 & 1.18 \\
\hline \multicolumn{10}{|l|}{ 3. Real rut farm incomes } \\
\hline ( $¥ 1000$ per hectare) & 475 & 908 & 913 & 1304 & 851 & 782 & 917 & 1057 & 965 \\
\hline Rates to national mean & 0.82 & 0.99 & 0.87 & 1.01 & 1.02 & 0.92 & 1.02 & 1.15 & 0.96 \\
\hline \multicolumn{10}{|l|}{ 4. Cost shares in gross farm } \\
\hline oulput : Kyushu & 36.8 & 38.2 & 49.3 & 47.6 & 62.2 & 670 & 64.6 & 64.2 & 69.7 \\
\hline Nationlal mean & 37.3 & 42.8 & 48.4 & 44.9 & 60.7 & 63.2 & 61.3 & 62.0 & 62.3 \\
\hline
\end{tabular}

Note: All of output ard input values are measured in constant 1990 prices, and output and input value per hectare is calculated at planted area base. However, the relative applieation rates of pesticides and fertilizer in parentheses are measured on cultivated area basc.

Source: Arca quantities of farm land are from the Statistics of Cultivated Land and Planted Area; Data on pesticide and fertilizer use, as well as net farm incomes and costs are from the Report of Farm Fconomy; Others are obtained from the Statistics of Agricultural Income, SIDMAFF.

agricultural cooperatives.

The intensive use of pesticides and commercial fortilizer has considerably contributed to labor-saving (Table 2). In rice production, labor hours per hectare applied to pest controlling steadily decreased by 88\%, from 341 hours in 1960 to 41 hours in 1997. Similar changes also occurred in fertilizing, as a result of substitution of commercial fertilizer for farm-source fertilizers with more intensive labor-use. Several major crops of this region presented in Table 2 exhibit higher decrease rates of labor time both in pest 
Table 2. Changes in Iabor Hours per Hectare: Crops with Continuous Records of Production Costs in Kyushu

\begin{tabular}{|c|c|c|c|c|c|c|c|c|c|c|}
\hline & 1960 & 65 & 70 & 75 & 80 & 85 & 90 & 95 & 97 & $\begin{array}{l}\text { Change Rates } \\
\text { for the Period }\end{array}$ \\
\hline Farm scetor mean & 2366 & 2321 & 2248 & 2218 & 1678 & 1619 & 1508 & 1336 & 1357 & -42.7 \\
\hline \multicolumn{11}{|l|}{ 1. Rice } \\
\hline Total & 1745 & 1323 & 1139 & 860 & 764 & 603 & 468 & 410 & 398 & -77.2 \\
\hline Fertilization & 66 & 57 & 60 & 47 & 44 & 41 & 33 & 25 & 25 & -62.1 \\
\hline Pest corttrol & 341 & 191 & 157 & 140 & 119 & 92 & 60 & 43 & 41 & -88.0 \\
\hline \multicolumn{11}{|l|}{$\begin{array}{l}\text { 2. Sweet potalo } \\
\text { for processing }\end{array}$} \\
\hline 'Total & 1146 & - & 896 & 806 & 832 & 778 & 758 & 733 & 729 & -36.4 \\
\hline Fertilization & 86 & - & 74 & 50 & 48 & 51 & 51 & 46 & 43 & -50.4 \\
\hline Pesi control & 302 & - & 197 & 178 & 164 & 122 & 116 & 102 & 98 & -67.7 \\
\hline 3. Orion & & & & $\cdot$ & & & & & & \\
\hline Total & - & - & $23 \% 8$ & 1350 & 1288 & $130 ; 3$ & 1343 & 1164 & 1009 & -57.2 \\
\hline Fertilization & - & - & 92 & 50 & 39 & $4 ; 3$ & 49 & 38 & 29 & -68.6 \\
\hline Pest control & - & - & 615 & 210 & 227 & 191 & 176 & 158 & 129 & -79.1 \\
\hline \multicolumn{11}{|l|}{ 4. Orange } \\
\hline Total & - & -- & 2956 & $23: 33$ & 1847 & 1954 & 1921 & 1926 & 1810 & -38.8 \\
\hline Fertilization & - & - & 212 & 100 & 97 & 138 & 110 & 106 & 83 & -60.9 \\
\hline Pest control & - & - & 778 & 660 & 475 & 480 & 5,33 & 464 & 363 & -53.4 \\
\hline
\end{tabular}

Note: The data on rice are the mean hours of Kyushu, whereas the data on swect potato for processing, onion: and orange represent respectively the mean hours of Kagoshima, Saga, and Kumamoto prefectures within this region. As the discontinuity of data, the 1997 data except rice are adjusted as follows:

The adjusted 1997 labor hours $=1994$ hours $/ 1995$ hours $\times 1997$ hours Source: The Report of Production Cost, SIDMAFF.

controlling and in fertilizing above total labor time, implying that the use of the two inputs may has generated more significant labor-saving cffects than agricultural mechanization.

On the oiher hanci, the productivity effects of intensive pesticide and fertilizer use are not necessarily determinate. Although land and labor produclivilies Incasured at real output value base have steadily grown, nct farm incomes per hectare exhibit obvious decline with violent variability after the mid-1970s, as the rapid rise in the share of production expense in gross farm output (Table 1). The diminishing or perhaps negative marginal returns of pesticides and fertilizer as well as associated negative environmental impact, which have been frequently pointed by many studies, then drive farmers to find out alternative production systems. According to Une(1987), a staff of agricultural extension agency in this region, the earliest farmers of LISF practices in Kyushu appeared around the mid-1970s. Table 3 presents a comparative survey about the number and percentages of LISF farmers in 1997 . With the exception of fruit vegetables (open field), all of the percentages of Kyushu are apparently higher than the national mean levels, implying that the efforts of farmers have made Kyushu the most representative region in environment-aware farming practices. Such changes in this region therefore provide 
Table 3. Number and Percentages of LISF Puclice Farmers

\begin{tabular}{|c|c|c|c|c|}
\hline & \multicolumn{2}{|c|}{ Kyushu } & \multicolumn{2}{|c|}{ National Mean } \\
\hline & Farmer & $\%$ & Farmer & $\%$ \\
\hline Rice & 23700 & 6.9 & 107300 & 5.5 \\
\hline \multicolumn{5}{|l|}{ Vegetables } \\
\hline Fruil vegetables (open field) & 1277 & 0.6 & 14900 & 0.8 \\
\hline Fruil, vegetables (protecled) & 5200 & 5.0 & 17700 & 0.9 \\
\hline Root vegetables & 5244 & 2.3 & 16200 & 0.8 \\
\hline Stem \& leaf vegetables & 6081 & 2.7 & 25300 & 1.3 \\
\hline Fruits & 7360 & 9.1 & 23200 & 4.7 \\
\hline
\end{tabular}

Note: The data are from Kyushu Agricultural Administration Officc.

favorite materials for examining the possibility of reducing pesticide and fertilizer use at a wide scope.

\section{Econometric analysis of pesticide and fertilizer use , A land-productivity-specific model}

The above discussion indicates that since the $1960 \mathrm{~s}$, pesticides and fertilizer have been used both as means of raising land productivity by preventing crops from pest. infestations and improving fertility of farmland, and as means of boosting labor productivity by facilitating substitution of the two inputs for labor in weed controlling and fertilizing which once were highly labor-intensive before these inputs were used. Under land-scarce conditions, land productivity is undoubtedly dominant either in product supply or in farm income, even though labor scarcity has substantially occured. Such features suggest that the economic model should be formulated based on land productivity considerations.

The examination in the preceding section also suggests that the increase in pesticide and fertilizer use has been influenced by market and non-market factors, and empirical work shouli explicitly incorporate these raciors into econometric process. Consider a production structure with multiproducts $\mathbf{F}\left(\mathbf{Y}^{\prime}, \mathbf{X}^{\prime}, \mathbf{Z}^{\prime}\right)=0$, where $\mathbf{Y}, \mathbf{X}, \mathbf{Z}$ are the vectors of output, variable inputs, and fixed or structural factors respectively. Let $\mathbf{A}$ denote land area, $y_{i}^{\prime} \subset \mathbf{Y}^{\prime}=\left(y_{i} / A_{i}\right) \vee i(i=1,2, \ldots, m)$ is land productivity of crop $i$, for example, output per hectare. Likewise, $\mathrm{x}_{\mathrm{j}}^{\prime} \in \mathbf{X}^{\prime}=\left(\mathrm{x}_{\mathrm{j}} / \mathrm{A}\right) \forall \mathrm{j}(\mathrm{j}=1,2, \ldots, \mathrm{n})$ and $\mathrm{z}_{\mathrm{k}}^{\prime} \in \mathbf{Z}^{\prime}=\left(\mathrm{z}_{\mathrm{k}} / \mathrm{A}\right) \forall \mathrm{k}(\mathrm{k}=1,2, \ldots, 0)$ are the amount per hectare of variable input $j$ and fixed or structural factor $k$ respectively. By the duality principle, there exists a corresponding indirect profit function:

$$
\pi^{\prime}=\phi\left(\mathbf{p}, \mathbf{r}, \mathbf{Z}^{\prime}\right)
$$

Where $\pi^{\prime}=(\pi / A)$ is defined as restricted unit profit, normalized by the numéraire price. $\mathbf{p}$ and $\mathbf{r}$ are the vectors of normalized prices of outputs and variable inputs. The roles of market and non-market factors in the production structure defined can be 
investigated through the price and non-price variables respectively. To obtain a coherent set of input demand and product supply equations, and to identify the effects of lowering the application rates of pesticides and fertilizer on input structure and product supply, as well as the interaction among the factors, a flexible functional form for the profit function (1) is preferred. This study employed the following quadratic form (Law, 1978).

$$
\begin{aligned}
& \pi^{\prime}=\alpha_{0}+\sum_{i} \beta_{i}^{\prime} p_{i}+\Sigma_{j} \gamma_{j} r_{j}+\sum_{k} \delta_{k} z_{k}^{\prime}+\frac{1}{2} \sum_{i} \Sigma_{i 2} \beta_{i z} p_{i j} p_{g}
\end{aligned}
$$

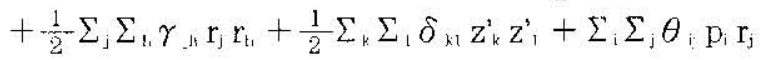

$$
\begin{aligned}
& +\sum_{i} \sum_{k} \kappa_{i k} p_{i} z_{k}^{\prime}+\sum_{j} \sum_{k} \mu_{j k} r_{i} z_{k}^{\prime} \\
& \beta_{i}=\beta_{i}+D
\end{aligned}
$$

Where I) denotes a weather variable. Applying Hotelling's Lemma to equation (2), a set of land-productivity-specific demand and supply equations can be obtained.

$$
\begin{aligned}
& -\left(\mathrm{X}_{\mathrm{j}} / \mathrm{A}\right)=-\mathrm{X}_{\mathrm{j}}^{\prime}=\partial \pi / \partial \mathrm{r}_{\mathrm{j}} \\
& =\gamma_{\mathrm{j}}+\Sigma_{\mathrm{k}} \gamma_{\mathrm{jh}} \mathrm{r}_{\mathrm{k}}+\Sigma_{\mathrm{j}} \theta_{\mathrm{jl}} \mathrm{p}_{\mathrm{j}}+\Sigma_{\mathrm{k}} \mu_{\mathrm{jk}}\left(\mathrm{z}_{\mathrm{k}} / \mathrm{A}\right) \\
& \left(\mathrm{Y}_{\mathrm{i}} / \mathrm{A}_{\mathrm{i}}\right)=\mathrm{Y}_{\mathrm{i}}^{\prime}=\partial \pi / \partial \mathrm{p}_{\mathrm{i}} \\
& \left.=\beta_{i}+\sum_{k} \beta_{i k} p_{k}+\sum_{i} \theta_{i j} r_{i}+\sum_{k} \kappa_{\mathrm{ik}}\left(Z_{k} / A\right)+D\right)
\end{aligned}
$$

Assume the qth variable input as pesticides or fertilizer. By equations (4) and (5), the responsiveness of demand of pesticides or fertilizer to changes in the prices of outputs and variable inputs, as well as fixed or structural factors can be summarized in elasticities as follows.

$$
\begin{aligned}
& \eta_{41}=\partial \operatorname{Ln}\left(X_{4} / A\right) / \partial \operatorname{Lnp}=\beta_{4 i} p_{i} /\left(X_{4} / A\right) \\
& \eta_{4}=\partial \operatorname{Ln}\left(X_{41} / A\right) / \partial \operatorname{Lnr}_{j}=\gamma_{1, j} r_{1} /\left(X_{4} / A\right) \\
& \eta_{4 k}=\partial \operatorname{Ln}\left(X_{4} / A\right) / \partial \operatorname{Ln}\left(z_{k} / A\right)=\mu_{4, k} Z_{k} / X_{4}
\end{aligned}
$$

Similarly, the effects of reducing pesticide or fertilizer use on output supply or yield per hectare can be evaluated either by cross-price elasticities $\nu_{i \text { it }}$ or by elasticities of production $\rho_{\mathrm{i} u}$, while the impact on labor dernand per hectare can be estimated using elasticities $\rho_{\mathrm{L}, 4}$.

$$
\begin{aligned}
& \nu_{\mathrm{ig}}=\theta_{\mathrm{is}_{\mathrm{j}}} \gamma_{\mathrm{q}} /\left(\mathrm{Y}_{\mathrm{i}} / \mathrm{A}_{\mathrm{i}}\right) \\
& \rho_{i q}=\theta_{i \mathrm{i}} \mathrm{X}_{4} \mathrm{~A}_{\mathrm{i}} / \theta_{\mathrm{il4}} \mathrm{Y}_{\mathrm{i}} \mathrm{A}=\nu_{\mathrm{iq}} / \eta_{\mathrm{qq}} \\
& \rho_{\mathrm{lul}}=\gamma_{\mathrm{Laq}} \mathrm{X}_{\mathrm{q}} / \gamma_{\mathrm{qq}} \mathrm{X}_{\mathrm{L}}=\nu_{\mathrm{laq}} / \nu_{\mathrm{qu}}
\end{aligned}
$$

\section{Empirical specification}

Agricultural output is disaggregated among rice, non-rice crops, and livestock. However, livestock is excluded from supply equations because of its low dependence upon land and the relatively minor amount of agrichemical use. According to MAFF (1998), the amount of chemical fertilizer applied to forage and manure crops is less than $5 \%$ of the total. No further division of non-rice outputs is made because of the inseparability of inputs among these crops. Variable inputs are divided into four categories: pesticide, fertilizer, labor, as well as energy and miscellaneous materials. 
Fixed or structural factors include planted areas, capital service, rent-charge, and weather. Since planted areas have been incorporated in equations (1) to (5), it is unnecessary to treat it as an independent variable.

Rent-charge is used as a structural variable representing the level of regional farming services utilized by individual farmers. According to Report of Farm Economy (RFE) by SIDMAFF, rent-charge includes the expenditures paid by farmers for machinery and implements owned by agricultural cooperatives or farmer organizations, the charges for the Joint Pest Management System, and the expenses for regional joint utilization facilities, including rice center, country elevator, nursery bed, as well as the grading, storage, and processing facilities for fruits and vegetables, etc. Thus, how the regional farming service system has related to input structure and product supply will be examined empirically.

\section{Data}

The data from four size classes of farm households, $0.5-1.0,1.0-1.5,1.5-2.0$, and 2.0 hectares or over in Kyushu, are used in model estimation. The sources of data are RFE and the Survey on Prices in Rural Areas (SPRA) published annually by SIDMAFF. Since 1995, the scope of farm households investigated has been confined to the "commercial farm household", and the size categories also increased. These make it difficult to utilize simultaneously the data before and after 1995 in the same estimation. Thus, only the data for the years 1962 to 1994 are used. The sample size then is $33 \times$ $4=132$.

Data on yield and pricc index of rice are directly available. The remaining output and input values are measured in constant 1990 prices. The aggregate output of non-rice crops is the sum of the real value of vegetables, fruits, industrial and other crops. The output per hectare of non-rice crops are obtained by dividing the aggregate output by the equivalent planted area used in production of these crops, which is calculated by subtracting the area used in rice, feed and forage crops from gross planted area. The aggregate price index of non-rice crops is constructed using a devisia index. The price indices of pesticides and fertilizer are directly available in SPRA, and the corresponding quantity indices of the two inputs are measured in real value term. The quantity of labor is represented by male-equivalent labor hours of family and hired workers. The male-equivalent labor hours of female workers are measured by multiplying the number of female labor hours by the daily wage ratio of female to male. The price of labor is computed by dividing hired labor expenditures by male-equivalent hired labor hours. The aggregate price index of energy and miscellaneous materials, which is also constructed using a devisia index, is used as numéraire to normalize the prices of outputs and variable inputs.

The quantity of capital service is derived by dividing agricultural machinery and implement cost by its price index. The same mothod is used to obtain the quantity of rent-charge. The amounts per hectare of variable and fixed factors are computed by dividing quantities on each categories of inputs by gross planted area. The weather variable is represented by cool summer damage. The years when cool summer damage occurred are given the value 1 , while other years are 0 . 


\section{Estimation results}

The estimating system in equations (4) and (5), excluding numéraire variablc, includes three input demand (pesticides, fertilizer, labor) and two product supply (rice

Table 4. Parameter Estimates of Input Demand and Product Supply Equations: Four Size Classes of Farm Households in Kyushu, 1962-94

\begin{tabular}{|c|c|c|c|c|c|}
\hline \multirow{2}{*}{$\begin{array}{l}\text { Explanatory } \\
\text { Variable }\end{array}$} & \multicolumn{3}{|c|}{ Demand Equations } & \multicolumn{2}{|c|}{ Supply Equations } \\
\hline & Pesticide & Fertilizer & Labor & Rice & Non-rice Crops \\
\hline Intercept & $\begin{array}{c}-2.06 \\
(2.12)\end{array}$ & $\begin{array}{c}-4.11 \\
(2.72)\end{array}$ & $\begin{array}{r}-149.42 \\
(8.70)\end{array}$ & $\begin{array}{l}286.83 \\
(11.81)\end{array}$ & $\begin{array}{c}20.34 \\
(1.16)\end{array}$ \\
\hline \multicolumn{6}{|l|}{ Normalized prices } \\
\hline Rice & $\begin{array}{c}3.13 \\
(5.61)\end{array}$ & $\begin{array}{c}-5.86 \\
(8.89)\end{array}$ & $\begin{array}{l}-81.81 \\
(6.55)\end{array}$ & $\begin{array}{c}89.70 \\
(4.41)\end{array}$ & $\begin{array}{r}69.07 \\
(5.50)\end{array}$ \\
\hline Non-rice crops & $\begin{array}{c}-0.06 \\
(0.01)\end{array}$ & $\begin{array}{c}-0.20 \\
(0.38)\end{array}$ & $\begin{array}{c}25.57 \\
(2.28)\end{array}$ & $\begin{array}{c}69.07 \\
(5.50)\end{array}$ & $\begin{array}{c}-68.34 \\
(4.96)\end{array}$ \\
\hline Pesticide & $\begin{array}{c}2.26 \\
(5.08)\end{array}$ & $\begin{array}{c}-2.00 \\
(3.88)\end{array}$ & $\begin{array}{c}-8.82 \\
(17.70)\end{array}$ & $\begin{array}{c}3.14 \\
(5.61)\end{array}$ & $\begin{array}{c}-0.01 \\
(0.01)\end{array}$ \\
\hline Fertilizer & $\begin{array}{c}-2.00 \\
(3.88)\end{array}$ & $\begin{array}{c}8.24 \\
(5.34)\end{array}$ & $\begin{array}{c}-3.41 \\
(5.80)\end{array}$ & $\begin{array}{c}-5.86 \\
(8.89)\end{array}$ & $\begin{array}{c}-0.20 \\
(0.38)\end{array}$ \\
\hline Labor & $\begin{array}{c}-8.82 \\
(17.70)\end{array}$ & $\begin{array}{c}-3.41 \\
(5.80)\end{array}$ & $\begin{array}{c}99.85 \\
(\quad 6.86)\end{array}$ & $\begin{array}{l}-81.81 \\
(6.55)\end{array}$ & $\begin{array}{r}25.57 \\
(2.28)\end{array}$ \\
\hline \multicolumn{6}{|l|}{$\begin{array}{l}\text { Fixed and } \\
\text { struclural factors }\end{array}$} \\
\hline Capital service & $\begin{array}{c}0.06 \\
(5.87)\end{array}$ & $\begin{array}{c}0.02 \\
(1.55)\end{array}$ & $\begin{array}{c}0.81 \\
(3.22)\end{array}$ & $\begin{array}{c}2.58 \\
(6.94)\end{array}$ & $\begin{array}{c}1.02 \\
(3.20)\end{array}$ \\
\hline Rent and charges & $\begin{array}{c}-0.25 \\
(6.03)\end{array}$ & $\begin{array}{c}-0.44 \\
(8.44)\end{array}$ & $\begin{array}{c}-6.29 \\
(4.82)\end{array}$ & $\begin{array}{c}2.84 \\
(1.76)\end{array}$ & $\begin{array}{c}10.16 \\
(7.95)\end{array}$ \\
\hline Cool summer duminy & - & - & - & $\begin{array}{l}-54.25 \\
(8.69)\end{array}$ & $\begin{array}{c}-4.71 \\
(1.10)\end{array}$ \\
\hline
\end{tabular}

Note: These results correspond to cquations (4) and (5). The t-statistics are in parentheses.

Table 5. Input Demand and Product. Supply Elasticities

\begin{tabular}{lrrrrr}
\hline \multirow{2}{*}{$\begin{array}{l}\text { Explanatory } \\
\text { Variable }\end{array}$} & \multicolumn{5}{c}{ Dependent Variable } \\
\cline { 2 - 6 } & Pesticide & Fertilizer & \multicolumn{1}{c}{ Labor } & Rice & Non-rice Crops \\
\hline Normalized prices & & & & & \\
$\quad$ Rice & -0.2502 & 0.4535 & 0.5976 & 0.1732 & 0.4994 \\
$\quad$ Non-rice crops & 0.0005 & 0.0171 & -0.2105 & 0.1503 & -0.5568 \\
$\quad \begin{array}{l}\text { Pesticide } \\
\text { Fertilizer }\end{array}$ & -0.1777 & 0.1576 & 0.7747 & 0.0060 & -0.0001 \\
$\quad$ Labor & 0.1526 & -0.6293 & 0.2906 & -0.0112 & -0.0014 \\
& 0.0635 & 0.0246 & -0.8030 & -0.1739 & 0.2035 \\
Fixed and & & & & & \\
structural factors & & & & & \\
$\quad$ Capital service & 0.1468 & 0.0460 & -0.1787 & 0.5092 & 0.2216 \\
$\quad$ Rent and charges & 0.2061 & 0.3575 & -0.4842 & 0.1968 & 0.7747 \\
\hline
\end{tabular}

Note: Elasticities are based the estimated parameters in table 4 and mean value of four size classes of farm households in 1994. 
and non-rice crops) equations. Consistent with equation (5), variable input quantitics are treated in negative units. Weather dummies only appear in supply equations since weather scems not to significantly affect input demand per hectare. After imposing cross-equation symmetry restrictions, the equations are jointly estimated using \%ellner's seemingly unrelated regression (SUR). The estimated results are presented in Table 4. Most of the parameters arc statistically significant at over $5 \%$ levels. Symmetry assumption is not rejected at the $1 \%$ significance level. Partial clasticities of input. demand and product supply based on the estimaled coefficients are reported in Table 5 .

\section{Influencing factors of pesticide and fertilizer application}

The effects of product prices on the application rates of pesticides and fertilizer are mixed. The demand elasticity of fertilizer with respect to rice price is 0.4535 and statistically significant at a $1 \%$ significance, whereas pesticide is estimated as negative value of elasticity. The cross-clasticities with respect to the aggregate price of non-rice crops are quite small, 0.0005 and 0.0171 respectively, and are not different from zero at. the $5 \%$ significance level. These results suggest that product prices are not necessarily the key factors of increasing pesticide and fertilizer use.

The own-price elasticities of pesticides and fertilizer are respectively -0.1777 and -0.6293 at the $1 \%$ confidence level. Consistent with the induced imovation hypothosis (Hayami and Ruttan, 1985), the diminishing relative price ratios to other inputs have significantly induced the use of the two factors. However, the low clasticities also imply that restrictions on agrichemical use through raising input prices or imposing taxes an uscrs may not necessarily be effective as might be expected, though the effects of restriction will be more notable on fertilizer than on pesticides.

The partial elasticities with respect to wage rate are as low as 0.0635 and 0.0246 respectively, though the estimated coefficients are significant, at a $1 \%$ level. By contrast. the cross-price elasticities of labor with respect to the two inputs are 0.7747 and 0.2906 , exhibiting obvious substitutabilities both between labor and pesticides and betwen labor and fertilizer. The two results indicate that pesticides and fertilizer applied in production have already been sufficiently abundant, whereas farm labor resources are relatively scarce, sensitively responding to changes in pesticides and fertilizer.

The substitution relationships between labor and the two inputs can be further recognized by comparing the cross-price elasticities of labor (0.7747 and 0.2906$)$ with the own-price clasticities of the two inputs $(-0.1777$ and -0.6293$)$. Using equation (11), the non-price cross clasticities of labor with respect to pesticides as well as fertilizer can be calculated as -4.3596 and -0.4618 respectively. A $10 \%$ reduction of pesticides will, ceteris paribus, generate a need of $44 \%$ increase in labor input, while the same percentage of reduction in fertilizer means an almost $5 \%$ increase in labor input. Moreover, as labor demand is sensitive to wage rate, with the own-price elasticity of 0.8030 , the price ratios of labor to pesticides and fertilizer will continue to be the dominant determinants of whether the LISF practices can be widely and rapidly adopted by farmers.

Regarding the fixed or structural factors, capital service is estimated to have positive effects on the use of pesticides and fertilizer, with the non-pricc cross elasticities of 0.1468 and 0.0460 respectively. The progress in agricultural mechanization has greatly 
promoted labor-saving while filling labor shortage, which then return to encourage substitution both of horbicides for cultural weed controlling and of purchased fortilizer for farm-source fertilizers. Similarly, the estimated elasticities of rent-charge suggest substitutability with labor, as well as complementarities with pesticides and fertilizer. The improvement in the regional farming service system, such as the Joint. Pest Management System and regional joint utilization facilities for production and marketing, is also labor-saving and agrichemical-using. On the supply equation side, rent-charge is cstimated as having positive effects on rice and non-rice product supply, with the cross elasticities of 0.1968 and 0.7747 at a $1 \%$ significance level. Combination of such results in demand and supply equations therefore reveals the dual character of the regional farming service system in agricultural development. On the one hand, it has strongly supported family farming under the "small-sized land ownership" by providing the improved farming services. However, on the other hand, it also seems to has placed the damper on the longer term development of agriculture due to inducing the excessive use of pesticides and fertilizer associated with environmental darnage.

\section{The possible impact of reducing pesticide and fertilizer use on yields and or farm incomes}

In the estimates of supply equations, the own-price elasticity of rice is 0.1732 , whereas non-rice crop exhibits at negative value $(-0.5568)$ at a $1 \%$ significance level. Serious sirplus of most food products and decline in product prices since the mid-1970s have directed farmers to choose higher value-added crops rather than more physical products per unit area when they make production decisions concerning non-rice crops. The pursuit of market-oriented crop composition can be the main reason of interpreting the negative elasticity.

The cross-price elasticities of rice and non-rice crops with respect to pesticides and fertilizer are all quite small, ranging from -0.0112 to 0.0060 . By the equation (10), this also means that elasticities of production of the two inputs are approximately zero or even negative. Pesticides and fertilizer have been obviously overused so that additional application is no longer accompanicd by increase in yield per unit area. Consequently, it is possible to reduce widely the use of the two inputs without or with less production or income loss.

\section{Conclusions and discussions}

Five meaningful conclusions can be drawn from this study.

(1) The conditions for reducing widcly the application rates of pesticides and fertilizer have been favorable, though this may vary across agricultural regions. The price inelasticity of supply with respect to the two inputs suggest that the widespread adoption of LISF practices is likely to be realized at lower opportunity cost. Basic strategy and policy action in line with three agroenvironment acts are required.

The productivity impact will, of course, depend on the degree of reduction of pesticide and fertilizer use. Several surveys have confirmed the possibility of $15-30 \%$ reduction of pesticide use and over $30 \%$ reduction of chemical fertilizer use without production loss (Kitajima 1994; the Institute of Japanese Agriculture 1998). The most recent survey from 2160 rice farmers, however, illustrated that a $50 \%$ reduction of 
chemical pesticides and fertilizer caused a $13.8 \%$ decline in yield per hectare (SIDMAFF, 1999). Such surveys provide powerful evidence for formulating the basic strategy and policy targets of lowering application rates of the two inputs.

(2) The policy considerations that purport to restrict the use of agrichemicals through raising factor prices or imposing taxes on users are unlikely to be effective as might. be expected because of the low price elasticitics of pesticides and fertilizer. Alternatively, price or market measures making LISF practices more profitable may effectively motivate farmers to adopt these practices.

(3) Education and extension are expected to play substantial roles in promoting the widespread adoption of LISF practices. As application rates of pesticides and fertilizer have technically been higher than their optimum levels, the input-use reduction is likely to contribute simultaneously to increasing net, income by saving costs and to lowering the negative environmental externalities arising from the use of such inputs. The "awareness effect" (I)'Souza el al., 1993) based on correct information and knowledge regarding the overused agrichemicals may help to induce more farmers to participate in LISF practices at lower policy cost.

(4) The fact that labor demand sensitively responds to changes in pesticides and fertilizer indicates that lowering application rates of the two factors means a need to increase labor input. Policy cfforts therefore are required both in encouraging the adoption of more labor intensive farming systems and in developing labor-saving technologies available in pest controlling and manure-treating. Direct payments as agroenvironment subsidies for farmers who have substantially contribited to reducing the negative environmental externalities by employing LISF practices, as well as the improvement in marketing environment concerning organic farm products are likely to be conducive to the adoption of labor-intensive farming systems.

(5) This study also suggests the necessity of promoting the transition of regional farming service system from agrichemical-using to more environment-sensitive pattern. This mainly includes both a transition from the conventional "Joint Pest Management System" to more flexible pest controlling systems with closer plot-monitoring of pest levels, and the transition of agricultural extension system from labor- or land-productivity bias to overall efficiency measures of all resources including environmental gain or cost. As transition costs, some additional investments may be inevilable ir less-polluting manure-handing systems, farm information systems, as well as staff training of agricultural extension agencies.

\section{REFERENCES}

Daberkov S. G, and Reichelderfer K. H., 1988. Low-iruput agriculture: trends, goals, and prospects for input use. American Journal of Agricultural Economics, Dec. pp. 1159-66.

J'Souza, G., D. Cyphers, and T. Phipps, 1993. Factors affecting the adoption of sustainable Oagricultural practices. Agricultural and Resource Economic: Review 22, pp. 159-65.

Fox, G., A. Weersink, G. Sarwar, S. Duff, and B. Deen., 1991. Comparative economics of 0altemative agricultural production systems: a review. N. E. J. Agr. and Resour. Econ. 20, pp. 124-42.

Havami, Y., and Ruttan, V. W., 1985. Agricultural development: an international perspective, Revised Edition, Johns Hopkins Lniversity Press, Baltimore.

Institute of Japanese Agriculture, 1998. Report on low input agriculture, in The Japan Agricultural News, Fab. 10. 
Kitajirna: T., 1994. The effects of fertilization improvernent in sustainable farming practices: $A$ case study in JA Kakamigahara district, Gihu Prefacture (in Japanese) [sehhi kaizen ni yoru kankyo hozen gatad nogyo no suishin: Gihuken $\mathrm{J} \Lambda$ Kakamihara\}. In National Federation of Agricultural Cooperative Associations (Eds.), The most recent cases of suslainable farming practices [JA 7er-Chn, JA Zen-Noh hen, saishin jirei: kankyo hozen gala nogyo]. Ienohikari kyokai Press, pp. 119 . 136 .

Lau, L. J., 1978. Applications of profit functions. In Melvyn Fuss and Daniel McFadden (eds.), Production Economics: A Dual Approach to Theory and Applications, Jorth Holland Publishing Company, New York, pp. 133-216.

MAFF, 1998, The Fertilizer Yearbook.

SIDMAFF, 1997. Survey on Sustainable Farming l'ractices.

SIDMAFF, 1999. Survey on Farm Economies with Sustainable Farming Practicos (Rico).

Lne, Y., 1987. Rice production practices with low pesticide use (in Japartese) [Gen noyaku no ine. tsukuri]. Nobunkyo Press.

Widawsty, I). S. Rozelle, S. Jin, J. Huang., 1998, P'esticide productivity, host-plant. resistance and productivity in China. Agricultural Economics 19, pp, 203-217.

Zelner, A., 1962, An efficient method of estinuting seemingly unrelated regressions and tests for aggregation bias. American Statistical Association Journal, 57(298), pp. 348-68. 